DOI: 10.46340/eppd.2020.7.3.33

Vladyslav Mykhailov

ORCID ID: https://orcid.org/0000-0001-8405-5153

Dnipropetrovsk State University of Internal Affairs, Ukraine

\title{
PUBLIC CONTROL AS A METHOD \\ OF PROVIDING LEGALITY AND DISCIPLINE IN THE ACTIVITIES OF THE PATROL POLICE
}

\author{
Владислав Михайлов
}

Дніпропетровський державний університет внутрішніх справ, Україна

\section{ГРОМАДСЬКИЙ КОНТРОЛЬ ЯК СПОСІБ ЗАБЕЗПЕЧЕННЯ ЗАКОННОСТІ ТА ДИСЦИПЛІНИ В ДІЯЛЬНОСТІ ПІДРОЗДІЛІВ ПАТРУЛЬНОї ПОЛІЦІї}

\begin{abstract}
The article is devoted to the characterization of public control, which is one of the important ways of ensuring lawfulness and discipline in the activities of patrol police units. The social conditionality of public control over patrol police activity as an important element of the National Police system of Ukraine has been clarified. Emphasis is placed on the purpose of public control, which is to optimize the patrol police, ensure strict compliance with the principles of law and discipline, respect for human and civil rights, eliminate existing differences and conflicts, outline prospects for further development of police activity. The concept and content of public control over police activity are defined and the subjects of such control are outlined, as well as a list of basic principles on which public activity in this field should be based. The ways of increasing the effectiveness of public control over patrol police activity in Ukrainian realities are suggested.
\end{abstract}

Keywords: control, public control, public, lawfulness, discipline, police, patrol police, forms of control, principles of control.

Вступ. Беручи до уваги те, що сучасні перетворення, які відбуваються в державі в цілому та в Міністерстві внутрішніх справ зокрема, мають чітку спрямованість на суспільство та громадянина, дотримання і захист прав якого поставлені на перше місце, аналізуючи питання про способи контролю за діяльністю поліції, не можна обійти увагою таку нову його форму, як громадський контроль.

Сама можливість здійснення контролю за діяльністю поліцейських передбачає їх підзвітність суспільству, що здатне погасити надмірність влади, яка народжує зловживання ${ }^{1}$. Слід констатувати, що сьогодні практично вся світова спільнота дійшла до усвідомлення непорушної істини, що визначає поліцію як організацію, яка служить для суспільства і на благо суспільства, а не навпаки ${ }^{2}$.

В Україні сучасний рівень розвитку суспільства знаходиться на тій стадії, коли до діяльності поліцейських підрозділів (за всіма їі напрямками) стали пред’являтися дійсно підвищені вимоги.

Адекватне і своєчасне реагування українських органів правопорядку на критичні зауваження та раціональні пропозиції, висловлювані суспільством в цілому і громадянами зокрема, сприяє не тільки виправленню помилок і попередженню їх небажаних наслідків, а й зміцненню законності, службової дисципліни, підвищенню рівня відповідальності.

Саме рівень довіри громадян на сьогодні $є$ основним критерієм оцінки ефективності діяльності органів і підрозділів поліції. Більше того, це перший і основний на сьогодні критерій

\footnotetext{
${ }^{1}$ Возможен ли народный контроль над полицией (2011). Интернет-журнал «Новая политика». $<$ http://www.novopol.ru>.

${ }^{2}$ Воронов, А.М., Кожуханов, Н.М. (2005). Общественное мнение как критерий оценки эффективности деятельности органов внутренних дел по обеспечению общественной безопасности. Российский следователь, 8. $<$ https://center-bereg.ru/m3826.html $>$.
} 
оцінки ефективності роботи патрульної поліції, а відтак науковий інтерес до подібного дослідження має очевидне практичне значення, оскільки за результатами такого аналізу генеруються нові знання, із яких можна витягти корисні уроки на майбутнє, визначити ключові напрямки проведення поліцейських реформ. Також можна передбачити проблеми, які можуть виникнути при реалізації поставлених завдань, розробити більш повну методологію розвитку правоохоронної системи, провести вчасні коректування вже розроблених програм реформування поліцейських підрозділів.

Стан дослідження проблеми. Попри значну кількість виконаних вченими досліджень проблем забезпечення законності та дисципліни в діяльності різних поліцейських підрозділів (варто згадати роботи В.Б. Авер'янова, О. Ф. Андрійко, В. М. Бевзенка, О. І. Безпалової, Ю. П. Битяка, В. В. Галунька, В. М. Гаращука, Т.О. Гуржія, С.Ф. Денисюка, Р. А. Калюжного, О. Ф. Кобзаря, Т. О. Коломоєць, В. К. Колпакова, А. Т. Комзюка, С. Ф. Константінова, О. В. Кузьменко, М. В. Лошицького, Р. С. Мельника, Т. П. Мінки, О.М. Музичука, Р.В. Миронюка, В. Я. Настюка, В. І. Олефіра, О. І. Остапенка, Д. В. Приймаченка, А. О. Собакаря, О.С. Юніна та ін. вчених), громадський контроль та форми його здійснення в них розглядаються однобічно, безсистемно, переважно активізуючись після резонансних порушень з боку працівників патрульної поліції.

Водночас, саме громадський контроль має значні можливості для оптимізації діяльність роботи патрульної поліції, забезпечення неухильного дотримання іiі працівниками принципів законності та дисципліни, дотримання прав людини і громадянина, усунення наявних розбіжностей та колізій, окреслення перспектив подальшого розвитку поліцейської діяльності.

Цими передумовами зумовлюється актуальність статті та ії мета, що полягає у необхідності 3'ясування сутності, змісту та особливостей громадського контролю як одного із важливих способів забезпечення законності та дисципліни в діяльності патрульної поліції, а також підвищення іiї ефективності в українських реаліях сьогодення.

Виклад основного матеріалу дослідження. Громадськість усі роки не була осторонь проблеми дотримання законності та дисципліни в діяльності української поліції, й така робота велась в цьому напрямку ще з середини 2000-х і врешті-решт привела до обмеженого успіху. Зокрема, у пункті 3 статті 11 Закону України «Про Національну поліцію» позначено, що «рівень довіри населення до поліції $є$ основним критерієм оцінки ефективності діяльності органів і підрозділів поліції». Разом з тим, реальні показники далекі від бажаних. Згідно з результатами оцінювання Харківського інституту стратегічних досліджень у 2018 році (19 500 респондентів), довіра до поліції становила 30,4\%. Дослідження Соціологічної групи «Рейтинг», проведене 19-22 жовтня 2019 року (2500 респондентів), показало рівень довіри поліції 32\%.

Основними принципами проведення оцінювання є об'єктивність опрацювання інформації про роботу органів і підрозділів Національної поліції, системність оцінювання якості їхньої роботи ${ }^{1}$. Важливим кроком в цьому напрямі стало схвалення Урядом 7 лютого 2018 року Порядку проведення оцінки рівня довіри населення до Національної поліції України, який містить базові правила щодо залучення незалежних соціологічних організацій до оцінки довіри, визначення періодичності тощо. В частині індикаторів (перемінні, які мають щороку повторюватись з метою відстеження динаміки за конкретно-визначений період) оцінки названий порядок відсилає до підзаконного акту, яким на сьогодні є наказ МВС України від 9 листопада 2018 р. № 900, що визначає індикатори, за якими здійснюється проведення оцінки, зокрема: стан злочинності; результативність діяльності органів і недоліки поліцейської діяльності; довіра до поліції та стосунки 3 населенням ${ }^{2}$. Таким чином нарешті зроблено крок до запровадження нової системи оцінки, водночас варто сказати, що необхідно зробити ще низку заходів для становлення цієї системи, аби вона не перетворилася на профанацію.

Цілком очевидно, що громадська думка в питанні оцінки і контролю за діяльністю поліції в рамках нових перетворень має не тільки наукове, але більшою мірою практичне значення,

\footnotetext{
${ }^{1}$ Постанова про затвердження Порядку проведення оцінки рівня довіри населення до Начіональної поліиії 2018 (Кабінет Міністрів України). Офіиійний сайт Верховної Ради Украӥни.

$<$ https://zakon.rada.gov.ua/laws/show/58-2018-\%D0\%BF\#n10>.

${ }^{2}$ Наказ про встановлення індикаторів, за якими здійснюється проведення оцінки рівня довіри населення до Національної поліщї̈ України 2018 (Міністерство внутрішніх справ України). Офіиійний сайт Верховної Ради України. <https://zakon.rada.gov.ua/laws/show/z1358-18>.
} 
особливо в аспекті забезпечення безпеки особистості, суспільства, держави від протиправних та інших злочинних посягань.

В цілому, багаторічний соціологічний моніторинг (2004 - 2019 роки) у сфері прав людини, дозволяє мати чітку картину того, яка кількість громадян щорічно стають потерпілими від порушень 3 боку поліції. Ця цифра змінювалася протягом двох десятиліть і в 2018 році становила 1,7\% населення. I хоча відсоток здається незначним, на практиці, це сотні тисяч українців з різних регіонів, які мали негативний досвід правопорушень з боку поліцейських. Так, згідно зі звітом, протягом останніх 12-ти місяців працівники поліції навмисно завдали побоїв, страждань чи катувань $19 \%$ українців. Також 18\% опитаних вказали, що з насильством з боку поліції стикалися їхні родичі, друзі і знайомі. Крім того, згідно з дослідженням, у 26\% опитаних у 2019 році виникала ситуація, в якій працівники поліції порушували їхні права, права їхніх близьких або недостатньо добре виконували свою роботу ${ }^{1}$.

Одним із дієвих способів протидії названим ганебним явищам є громадський контроль, що розглядається як важлива форма реалізації демократії, оскільки дає можливість населенню брати участь у державному управлінні, у вирішенні державних і суспільних справ, активно впливати на діяльність органів державної влади та місцевого самоврядування ${ }^{2}$. Тобто, громадський контроль розглядається як інструмент громадської оцінки ступеня виконання органами влади та іншими підконтрольними об'єктами їхніх соціальних завдань.

Соціальний аспект громадського контролю уз'ясуванні його сутності $є$ ключовим, адже, слушно наголошує О.М. Музичук про те, що такий контроль є одним із видів соціального контролю, що здійснюється об'єднанням громадян та самими громадянами, є формою реалізації демократії і залучення населення до управління суспільством і державою³.

Характерні відмінності громадського контролю від будь-якого іншого виду контролю лежать у суб'єктно-об'єктній сфері і полягають у тому, що, по-перше, громадський контроль здійснюється саме громадськістю (організованою та неорганізованою), і, по-друге, що у процесі здійснення громадського контролю контролюється виконання саме соціальних завдань, безпосередньо пов'язаних із захистом і реалізацією прав і свобод громадян, задоволенням та узгодженням соціальних потреб та інтересів населення ${ }^{4}$. Крім того, на думку вчених, завдання громадського контролю полягає у тому, щоб не допустити дій контрольованих суб'єктів за межами законності й правопорядку, попередити можливі відхилення від намічених цілей, а також інтересів суспільства та його суб'єктів, а у разі появи цих відхилень усунути їх негативні наслідки 5 .

Отже, громадський контроль $є$ властивістю громадянського суспільства і виступає в якості однієї з його основних функцій. За допомогою громадського контролю формуються стандарти правомірної діяльності як самого суспільства, так і окремих його індивідів, груп та інститутів, в тому числі й патрульної поліції. При цьому ознаки громадського контролю полягають в тому, що він: виступає в якості форми управління суспільством і окремими його інститутами; являє собою важливий засіб забезпечення балансу інтересів різних соціальних груп і недопущення конфліктів даних інтересів; є методом координації і об'єднання зусиль суспільства для вирішення невідкладних завдань; виступає в якості гаранта виконання соціальних норм, оскільки дозволяє виявити порушників і розробити механізм залучення їх до громадської відповідальності, починаючи з громадського осуду і закінчуючи правовою відповідальністю, яка може виразитися в застосуванні до правопорушників заходів примусового характеру (наприклад, за підсумками розгляду звернень громадян в органи державної влади та місцевого самоврядування); допомагає виявити факти грубих, систематичних, масових порушень прав людини.

\footnotetext{
1 Это «доверие» к полиции сломалось. Несите другое. Украинская правда. $<$ https://www.pravda.com.ua/rus/columns/2020/02/18/7240864/>.

${ }^{2}$ Іжа, М. (2012). Громадський контроль в системі публічного управління як ефективний інструмент експертизи державно-управлінських рішень. Публічне управління: теорія та практика, 4(12), 75.

${ }_{3}^{3}$ Музичук, О.М. (2010). Проблеми класифікації контролю за діяльністю правоохоронних органів в Україні. Право і безпека, 2 (35). <http:// www.nbuv.gov. ua/portal/soc_gum/Pib/2010_3/PB-3/PB-3_18.pdf>.

${ }^{4}$ Іжа, М. (2012). Громадський контроль в системі публічного управління як ефективний інструмент експертизи державно-управлінських рішень. Публічне управління: теорія та практика, 4(12), 75.

5 Ярмакі, Х.П. (2014). Громадський контроль в Україні. Роль та місие ОВС у розбудові демократичної правової держави: матеріали VI Міжнародної науково-практичної конференції (4 квітня 2014 р.). Одеса: ОДУВС, 15-16.
} 
3 урахуванням викладеного громадський контроль за діяльністю патрульної поліції слід розуміти як визначену законом діяльність представників громадськості (як індивідуальних, так і колективних суб'єктів), спрямовану на перевірку (спостереження, нагляд) за законністю виконання завдань патрульними підрозділами Національної поліції щодо забезпечення публічної безпеки і порядку, охорони прав і свобод людини, а також інтересів суспільства і держави, протидії злочинності, надання в межах, визначених законом, послуг з допомоги особам, які з особистих, економічних, соціальних причин або внаслідок надзвичайних ситуацій потребують такої допомоги ${ }^{1}$.

Відповідно до чинного законодавства, а зокрема розділу VIII «Громадський контроль за діяльністю поліції» Закону України «Про Національну поліції», нормативно визначено такі форми публічного контролю за діяльністю поліції: отримання i оприлюднення звіту про поліцейську діяльність; контроль за діяльністю керівника поліції і прийняття резолюції недовіри йому; взаємодія між керівниками територіальних органів поліції і представниками органів місцевого самоврядування; залучення громадськості до розгляду скарг на дії або бездіяльність поліцейських тощо.

Слід зазначити, що з числа різноманітних форм публічного контролю за діяльністю поліції в зарубіжних країнах найбільш ефективною $є$ активна участь громадськості у взаємодії з поліцією, спрямованої на прийняття ряду превентивних заходів, спрямованих на недопущення (мінімізації) порушень публічного порядку, і ліквідації наслідків таких порушень, особливо на місцевому рівні, зокрема: прийняття участі в патрулюванні адміністративно-територіальних одиниць (вулиць, парків, скверів, спортивних, музичних та інших розважальних арен, об'єктів громадського транспорту); участь в проведенні спільних нарад з представниками територіальних громад; участь в охороні публічного порядку в разі посиленого варіанту несення служби поліцією. Тут слід зазначити, що таке залучення громадськості до спільної діяльності з поліцією відбувається в переважній більшості з ініціативи громадян, і тільки у винятковому випадку, наприклад при ліквідації наслідків стихійного лиха, з ініціативи поліції або органів публічної влади.

На жаль, у чинному законодавстві, а зокрема розділі VIII «Громадський контроль за діяльністю поліції» Закону України «Про Національну поліцію», такі форми взаємодії громадськості і поліції не знайшли свого нормативного закріплення, і мабуть цьому є причина, пов'язана з тим, що багаторічна практика залучення громадськості до участі в діяльності тодішньої міліції зводилася до примусового залучення громадян у ролі народних дружинників до охорони публічного порядку, останнім часом не мала своєї ефективності ${ }^{2}$.

Поліцейська реформа привнесла нові форми громадського контролю за діяльністю поліції. Частиною нових його форм та одним із найважливіших елементів підвищення прозорості їі діяльності є створення різного роду комісій, до яких обов'язково залучаються представники громадськості і які безпосередньо мають можливість впливу на кадрову політику в Національній поліції. Однойменний закон вперше в історії вітчизняних органів правопорядку передбачив можливість постійної широкої участі громадськості через поліцейські комісії у вирішенні важливих питань набору поліцейських та встановлення пріоритетів діяльності для територіальних органів поліції ${ }^{3}$

Діяльність поліцейських комісій врегульована як положеннями Закону України «Про Національну поліцію», так і підзаконними нормативно-правовими актами. Зокрема, відповідні положення містяться: у статтях 51-55 та 86 Закону «Про Національну поліцію»; у Порядку діяльності поліцейських комісій 5 , а також Типовому порядку проведення конкурсу на службу до поліції та/або зайняття вакантної посади ${ }^{6}$, затверджених Наказом МВС України від 25.12.2015 р.

\footnotetext{
${ }^{1}$ Поклад, О.В. (2016). Поняття та зміст громадського контролю за діяльністю поліції в Україні. Право $i$ суспільство, 2, 144.

${ }^{2}$ Миронюк, Р.В. (2018). Міжнародні стандарти громадського контролю за діяльністю поліції. Правові та організаиійні засади забезпечення державою правоохоронної функиії: матеріали Всеукраїнської науковопрактичної конференції (Дніпро, 30 жовт. 2018 р.). Дніпро: Дніпроп. держ. ун-т внутр. справ, 161.

${ }^{3}$ Банчук, О. (ред.) (2017). Громадськість і органи правопорядку: контроль, моніторинг, співпраия: практичний посібник. Київ: Москаленко О.М., 4.

${ }_{4}^{4}$ Закон про Наиіональну поліиію 2015 (Верховна Рада України). Відомості Верховної Ради України, 40-41, 379.

${ }^{5}$ Наказ про Порядок діяльності поліщейських комісій 2015 (Міністерство внутрішніх справ України).

Офіиійний вісник України, 2016, 6, 320.

${ }^{6}$ Наказ про Типовий порядок проведення конкурсу на службу до поліиї та/або зайняття вакантної посади 2015 (Міністерство внутрішніх справ України). Офічійний вісник Украӥни, 2016, 6, 320.
} 
№ 1631. Цими нормативно-правовими актами врегульовано порядок залучення комісій до вирішення кадрових питань у поліції, підстави для формування комісій, питання організаційного забезпечення їхньої роботи тощо. Водночас існує низка прогалин та колізій в актах законодавства, які регулюють діяльність поліцейських комісій. Згідно із Законом у структурі органів Національної поліції утворюються постійні поліцейські комісії, покликані забезпечити прозорість набору (конкурс) та просування по службі поліцейських на підставі об'єктивного оцінювання професійного рівня та особистих якостей кожного поліцейського, відповідності їх посаді, визначення перспективи службового використання в органах поліції.

Основними повноваженнями поліцейських комісій, визначеними в частині 4 статті 51 Закону України «Про Національну поліцію», є: 1) проведення відбору (конкурсу) на службу в органи (заклади, установи) поліції, крім прийому на навчання до вищих навчальних закладів із специфічними умовами навчання, які здійснюють підготовку поліцейських; 2) проведення конкурсу для призначення на вакантну посаду. Закон передбачає також неосновні або додаткові повноваження поліцейських комісій, до яких можна зарахувати встановлення пріоритетів для поліції та територіальних органів поліції (частина 2 статті 86), які в нинішніх умовах потребують додаткового врегулювання, насамперед в частині впровадження на практиці положень зазначеного закону щодо встановлення комісіями пріоритетів діяльності для територіальних органів поліції.

Отже, громадський контроль за діяльністю поліції крім відповідного нормативного забезпечення має будуватися на певних принципах, до яких слід віднести: принцип верховенства права, змістом якого $є$ визнання права вищою суспільною цінністю, вимога здійснення контролю виключно у правовому полі держави; принцип законності, тобто імператив регламентації процедури та компетенції контролюючих органів; принцип позапартійності, тобто унеможливлення впливу політичних сил на його здійснення; принцип демократизму, що передбачає залучення широких верств населення до процесу контролю; принцип гласності та демократичної підзвітності, що містить заборону визнавати результати контролю секретними та приховувати їх від громадськості; принцип прозорої діяльності контролюючих суб'єктів.

До системи суб’єктів громадського контролю за діяльністю Національної поліції України слід віднести виключно ті елементи суспільної системи, які існують поза державою: утворення (інститути) громадянського суспільства, органи місцевого самоврядування, громаду, громадські (суспільні) організації, органи самоорганізації населення, засоби масової інформації, громадяни.

Висновок. Таким чином, громадський контроль виступає в якості дієвого інструменту забезпечення належного стану підтримання законності та дисципліни в діяльності патрульної поліції, дотримання відкритості та гласності в роботі іiі працівників, подолання неприйнятної для суспільства системи звітності за показниками, підвищення ефективності якого вбачається за рахунок:

- чіткого нормативного закріплення процедури співбесіди кандидата на посаду працівника патрульної поліції шляхом з'ясування рівня його професійних, морально-ділових, управлінськоорганізаторських компетенцій;

- законодавчого визначення обмежених термінів оприлюднення результатів кожного етапу випробування під час конкурсу на посаду працівника патрульної поліції та можливості присутності під час проведення конкурсу представників громадськості;

- законодавчого наділення атестаційних комісій повноваженнями щодо підготовки висновків про невідповідність поліцейського займаній посаді;

- залучення громадськості до вироблення та належного законодавчого закріплення переліку критеріїв оцінювання ефективності діяльності патрульної поліції, що мають бути як загальними (наприклад, врахування виключно громадської думки), так і спеціальними (враховувати специфіку виконання патрульними поліцейськими оперативно-службових завдань в типових та екстремальних ситуаціях). Необхідність розмежування таких критеріїв на групи зумовлено тим, що рівень довіри населення є суб'єктивним критерієм оцінювання ефективності діяльності поліції, а відтак не може бути єдиним під час моніторингу стану оперативно-службової діяльності ії патрульних підрозділів;

- належного інформаційного забезпечення роботи поліцейських комісій тощо.

Громадський контроль за діяльністю патрульної поліції є набором правових інструментів і засобів моніторингу та оцінки законності виконання покладених на патрульну поліцію функцій. Громадський контроль $€$ найвищим проявом демократичності та правосвідомості суспільства, адже 
самі громадяни за допомогою правових засобів впливу не дають працівникам патрульної поліції виходити за встановлені законом межі.

\section{References:}

1. Banchuk, O. (ed.) (2017). Hromadskist i orhany pravoporiadku: kontrol, monitorynh, spivpratsia: praktychnyi posibnyk [Public and law enforcement agencies: control, monitoring, cooperation: a practical guide]. Kyiv: FOP Moskalenko O.M. [in Ukrainian].

2. Vozmozhen li narodnyj kontrol' nad policiej [Is People's Control Over the Police Possible?] (2011). Internet-zhurnal «Novaja politika» [Newspaper Online Magazine]. <http://www.novopol.ru>. [in Russian].

3. Voronov, A.M., Kozhuhanov, N.M. (2005). Obshhestvennoe mnenie kak kriterij ocenki jeffektivnosti dejatel'nosti organov vnutrennih del po obespecheniju obshhestvennoj bezopasnosti [Public opinion as a criterion for evaluating the effectiveness of the activities of internal affairs bodies in ensuring public safety]. Rossijskij sledovatel' [Russian investigator], no. 8. <https://center-bereg.ru/m3826.html>. [in Russian].

4. Zakon pro Natsionalnu politsiiu 2015 [Law on the National Police] (Verkhovna Rada Ukrainy) [(Verkhovna Rada of Ukraine)]. Vidomosti Verkhovnoi Rady Ukrainy [Information of the Verkhovna Rada of Ukraine], 40-41, 379. [in Ukrainian].

5. Izha, M. (2012). Hromadskyi kontrol v systemi publichnoho upravlinnia yak efektyvnyi instrument ekspertyzy derzhavno-upravlinskykh rishen [Public control in the system of public administration as an effective tool for the examination of public administration decisions]. Publichne upravlinnia: teoriia ta praktyka [Public administration: theory and practice], no. 4(12), 75. [in Ukrainian].

6. Myroniuk, R.V. (2018). Mizhnarodni standarty hromadskoho kontroliu za diialnistiu politsii [International standards of public control over police activities]. Pravovi ta orhanizatsiini zasady zabezpechennia derzhavoiu pravookhoronnoi funktsii: materialy Vseukrainskoi naukovo-praktychnoi konferentsii (Dnipro, 30 zhovt. 2018 r.) [Legal and organizational principles of state enforcement of the law enforcement function: materials of the All-Ukrainian scientific-practical conference (Dnipro, October 30, 2018)]. Dnipro: Dniprop. derzh. un-t vnutr. sprav, 161. [in Ukrainian].

7. Muzychuk, O.M. (2010). Problemy klasyfikatsii kontroliu za diialnistiu pravookhoronnykh orhaniv v Ukraini [Problems of classification of control over the activities of law enforcement agencies in Ukraine]. Pravo i bezpeka [Law and security], no. 2 (35). <http://www.nbuv.gov. ua/portal/soc_gum/Pib/2010_3/PB-3/PB-3_18.pdf>. [in Ukrainian].

8. Nakaz pro vstanovlennia indykatoriv, za yakymy zdiisniuietsia provedennia otsinky rivnia doviry naselennia do Natsionalnoi politsii Ukrainy 2018 [Order on the establishment of indicators for assessing the level of public confidence in the National Police of Ukraine] (Ministerstvo vnutrishnikh sprav Ukrainy) [(Ministry of Internal Affairs of Ukraine)]. Ofitsiinyi sait Verkhovnoi Rady Ukrainy [Official site of the Verkhovna Rada of Ukraine]. $<$ https://zakon.rada.gov.ua/laws/show/z1358-18>. [in Ukrainian].

9. Nakaz pro Poriadok diialnosti politseiskykh komisii 2015 [Order on the Procedure for the Activities of Police Commissions] (Ministerstvo vnutrishnikh sprav Ukrainy) [(Ministry of Internal Affairs of Ukraine)]. Ofitsiinyi visnyk Ukrainy [Official Bulletin of Ukraine], 2016, 6, 320. [in Ukrainian].

10. Nakaz pro Typovyi poriadok provedennia konkursu na sluzhbu do politsii ta/abo zainiattia vakantnoi posady 2015 (Ministerstvo vnutrishnikh sprav Ukrainy) [(Ministry of Internal Affairs of Ukraine)]. Ofitsiinyi visnyk Ukrainy [Official Bulletin of Ukraine], 2016, 6, 320. [in Ukrainian].

11. Poklad, O.V. (2016). Poniattia ta zmist hromadskoho kontroliu za diialnistiu politsii v Ukraini [The concept and content of public control over the activities of the police in Ukraine]. Pravo i suspilstvo [Law and society], no. 2, 144. [in Ukrainian].

12. Postanova pro zatverdzhennia Poriadku provedennia otsinky rivnia doviry naselennia do Natsionalnoi politsii 2018 [Resolution on approval of the Procedure for assessing the level of public confidence in the National Police] (Kabinet Ministriv Ukrainy) [(Cabinet of Ministers of Ukraine)]. Ofitsiinyi sait Verkhovnoi Rady Ukrainy [Official site of the Verkhovna Rada of Ukraine]. $<$ https://zakon.rada.gov.ua/laws/show/58-2018-\%D0\%BF\#n10>. [in Ukrainian].

13. Jeto «doverie» k policii slomalos'. Nesite drugoe [This "trust" in the police has broken. Carry another]. Ukrainskaja pravda [Ukrainian truth]. <https://www.pravda.com.ua/rus/columns/2020/02/18/7240864/>. [in Russian].

14. Yarmaki, Kh.P. (2014). Hromadskyi kontrol v Ukraini [Public control in Ukraine]. Rol ta mistse OVS u rozbudovi demokratychnoi pravovoi derzhavy: materialy VI Mizhnarodnoi naukovo-praktychnoi konferentsii (4 kvitnia 2014 r.) [The role and place of police in building a democratic state governed by the rule of law: materials of the VI International Scientific and Practical Conference (April 4, 2014)]. Odesa: ODUVS, 15-16. [in Ukrainian]. 